\title{
Norway: Submerged Stone Age from a Norwegian Perspective
}

\author{
Håkon Glørstad, Jostein Gundersen, Frode Kvalø, \\ Pål Nymoen, David Simpson, and Birgitte Skar
}

\begin{abstract}
The presence of submerged Stone Age sites along the Norwegian coast has been recognised for a long time. Until recently, however, they have not been treated as a topic of interest. From shallow waters, more than 80 submerged Stone Age sites are known in Norway, one of which is a probable ritual site with bones of several humans. Due to complex patterns of shoreline displacement and uplift after the last deglaciation, the present-day shallow water areas along the Norwegian coast contain sites from periods which are also represented by numerous sites on dry land. The submerged
\end{abstract}

H. Glørstad $(\bowtie)$

Museum of Cultural History, University of Oslo, Oslo, Norway

e-mail: hakon.glorstad@khm.uio.no

J. Gundersen

Directorate for Cultural Heritage, Oslo, Norway

e-mail: jog@ra.no

F. Kval $\varnothing \cdot$ P. Nymoen

Norwegian Maritime Museum, Oslo, Norway

e-mail: frode.kvalo@marmuseum.no;

pal.nymoen@marmuseum.no

D. Simpson

University Museum of Bergen, University of Bergen,

Bergen, Norway

e-mail: david.simpson@uib.no

B. Skar

NTNU University Museum, Norwegian University of Science and Technology, Trondheim, Norway

e-mail: birgitte.skar@ntnu.no sites can provide better preservation quality for cultural remains of organic materials than settlement sites on dry land. This allows for a dynamic and informed study of Stone Age coastal adaptations, interactions and lifeways.

\section{Keywords}

Submerged Stone Age · Postglacial ·

Colonisation · Mesolithic .

Hummervikholmen · Isostasy

\subsection{Introduction}

The sea has always been central to Norwegian Stone Age research, not least because the vast majority of all known Stone Age sites are situated close to present or ancient coastlines. Norway today has a productive coastline 83,281 km long, including islands (Statistics Norway 2013); also during the Stone Age period the coast in practice constituted most of the habitable land of the country because of a mountainous or ice-bound hinterland which even today offers only a very small percentage of land suitable for cultivation. The close connection between ancient habitation patterns and the sea therefore comes as no surprise. Site location, dietary evidence, and, recently, various isotope and other chemical analyses all point towards heavy dependence on the marine ecosystem 
throughout the Stone Age. Consequently, variations in sea level throughout prehistory have had a large impact on human occupation and the preservation of Stone Age sites. A combination of changes in global sea level (eustasy) and isostatic rebound following the melting of the Scandinavian ice shield in the Holocene has created not only a varied and complicated history of the interplay between humans and the sea but also a complicated preservation history of Stone Age sites. Along the coastline, all variants of this dynamic interplay can be demonstrated, from coastlines that have undergone continuous postglacial rebound and uplift where the ice sheet was at its thickest, to areas dominated by transgression and inundation.

The fact that Stone Age sites can be found associated with all variants of these geological processes has long been acknowledged in Norwegian archaeology. This awareness has also grown as more precise shoreline displacement curves have been presented by geologists and pollen analysts. Nevertheless, most scientific attention has focussed on Stone Age sites preserved on dry land.

There are many reasons for this terrestrial focus. Land uplift attracted more scientific interest than inundation at the beginning of the twentieth century, and consequently settlement history was also directed towards elevated coastlines (for instance Brøgger 1905). Technical limitations connected to underwater archaeology were also an obvious limitation until approximately 1955-65, when diving equipment became more easily available. Sites on land also provided a rich foundation for establishing information on the chronology, typology, settlements and adaptations of the Norwegian Stone Age. The interest in a submerged settlement history, however, remained active-not least in a fascination with the lost plains of the North Sea Continent.

\subsection{The North Sea Continent and the Postglacial Colonisation of the Norwegian Coastline}

In the archaeological literature, the now submerged North Sea Plains, popularly known as Doggerland, are considered to be of great importance for early human settlement in NorthWestern Europe (Reid 1913; Coles 1998; Gaffney et al. 2017), and a possible bridgehead for the colonisation of Norway at the end of the last Ice Age (e.g., Nummedal 1923; see Bjerck 1994, 1995 and Glørstad et al. 2017 for a critical discussion). So far, there is no evidence for prehistoric human settlement in the Norwegian sector of the North Sea Plains lying to the west of the Norwegian Trench (Fig. 6.1). Even if human populations were present there during the Last Glacial Maximum, it appears unlikely that this was the source region for the pioneer colonisation of the Scandinavian Peninsula since this would have required a sea crossing over what would always have been a wide and inhospitable expanse of open sea. It is more probable that the first inhabitants entered the country via the Swedish west coast (Bjerck 2008; Hafeez et al. 2012; Glørstad 2012; Glørstad and Kvalø 2012; Glørstad et al. 2017).

Despite the fact that most of the Norwegian coastline had been ice-free from the Allerød Oscillation (11,800-10,600 cal BC), access was blocked either by large distances of open sea or by the Scandinavian Glacier (Glørstad 2014). Only after about 9200 cal BC did an ice-free passage open up from Bohuslän in Sweden to the Oslo fjord area. By this route humans could travel in sheltered waters, navigating with land constantly in sight. Consequently, the whole Norwegian coast became easily accessible for settlement. Bohuslän was probably one of the most densely populated areas in Europe at the 


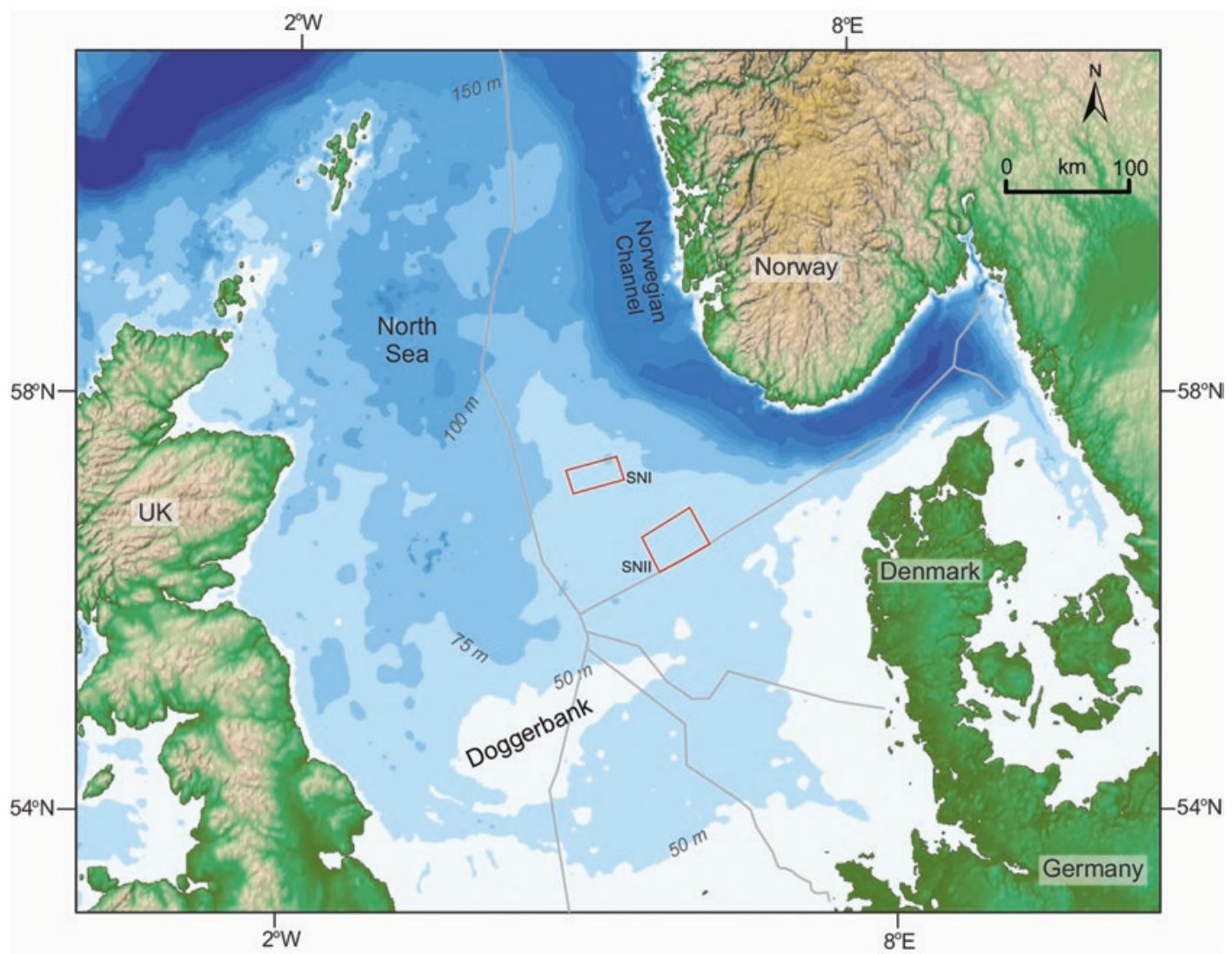

Fig. 6.1 Hypothetical drainage channels and maximum extent of Doggerland at the Late Glacial Maximum (from Glørstad et al. 2017, figure 19.2). SNI and SNII indicate locations where coring in advance of wind-farm development has demonstrated the former land surface of Doggerland buried beneath marine sediments associated with the inundation by sea-level rise before the end of the Last Ice Age. The Norwegian trench would always have been a barrier to movement into the ice-free coastal regions of Norway to the north, while the ice sheet would have blocked access from southern Norway and Sweden to the south until the final stages of ice retreat at the very end of the Last Ice Age

end of the Pleistocene because of a very rich marine ecosystem (Schmitt et al. 2006). This relatively large population would have enabled a rapid colonisation of the Norwegian coast in the Preboreal period (Berg-Hansen 2017). There is also growing evidence at the beginning of the Boreal period for the spread of new immigrants into northern Norway entering from the North East (Sørensen et al. 2013; Damlien 2014, 2016; Günther et al. 2018).

\subsection{The Scandinavian Peninsula-An Archive of Early Coastal Settlements}

The allure of the North Sea Continent clearly demonstrates an early if speculative interest in the submerged Stone Age in Norway. Ancient coastal settlements preserved on dry land have perhaps rightfully received much more scien- 


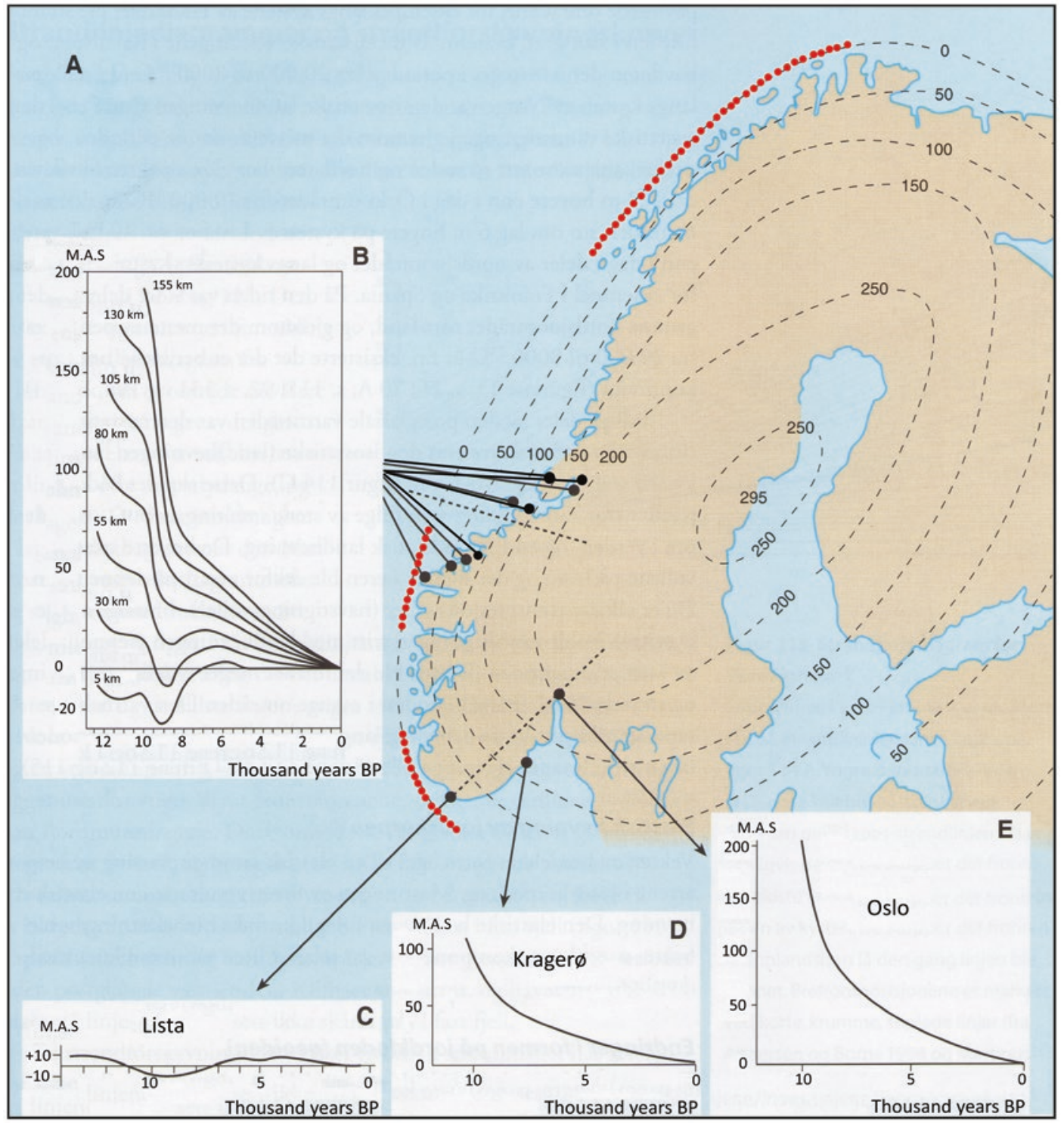

Fig. 6.2 The combined effect of sea-level rise (eustasy) and land uplift (isostasy). Broken contour lines in the main figure (a) show uplift, and red dotted lines show the three areas with submerged Stone Age shorelines. So far, only the two southernmost areas have yielded underwater Stone Age finds. Figures b, c, $\mathbf{d}$ and $\mathbf{e}$ present relative sea-level change in different areas. Figure $\mathbf{b}$ is a suite of seven sea-level curves derived from nine shoreline diagrams indicated by a black dot on map a. The curves in figure b were constructed for every $25 \mathrm{~km}$ along the projection plane indicated with a stippled line perpendicular to the uplift lines on map a. The stippled line between the Lista and Oslo curves is the projection plane in this area. Modified from Andersen 2000

tific attention, because the Scandinavian Peninsula offers rather unusual possibilities for the study of marine lifeways in a long-term perspective. In most parts of the world, Early Holocene coastal areas are now inundated. This also goes for most of Europe, meaning that potential early shore-bound settlements are now submerged. Due to the great thickness of the Pleistocene ice shield, the Scandinavian Peninsula underwent rapid isostatic uplift, parallel with and in some areas outstripping the sea-level rise as the weight from the ice 
diminished during the Late glacial period, resulting in elevated ancient shorelines.

The general picture is one of relative and continuous land rise, a process that is still on-going (Andersen 2000) (Fig. 6.2). Because of this geological process, whole coastal landscapes with Stone Age settlement sites, dating back to the beginning of the Holocene, are easily accessible to archaeology above water. This situation has made it possible for Norwegian and Swedish archaeologists to contribute very significantly to the understanding of the importance of early coastal adaptations in European prehistory (e.g. Brøgger 1905; Bagge 1951; Fredsjö 1953; Mikkelsen 1975; Bjerck 1986; Olsen, 1994; Fischer 1995; Åkerlund 1996). Coastal settlements in Scandinavia are among the oldest welldocumented, maritime societies in the world, going back to the final part of the Ice Age (Younger Dryas) (Schmitt et al. 2009). The continuous occupation of an uplifting coastline has enabled Scandinavian archaeologists to establish a very precise chronological development of the Stone Age, contrary to the situation further to the south. The documentation of this long-lived Scandinavian maritime tradition is an important contribution to our understanding of human reliance on marine resources and coastal communication. Consequently, this is of crucial importance for the future investigation of submerged Stone Age sites in Europe.

Looking closer into the different regions of Norway, a more varied and perhaps challenging picture appears, because land rise was not equally marked all over the country. Already at the end of the nineteenth century it was demonstrated that the Scandinavian Peninsula was subjected to a rise in sea level approximately 10,000 years ago - the socalled Tapes transgression (De Geer 1888). Dependent on local isostasy, the effect of this global sea-level rise varies considerably in Norway.

In south-east Norway, a land rise of c. $50 \mathrm{~m}$ is recorded around the Oslo Fjord in the earliest settlement phase, c. 9500-8000 cal BC (Jaksland and Persson 2014), similarly in the south Swedish Bohuslän region, a eustatic regression rate of 2.5-3.0 m/100 year is recorded during the period c. 10,000-9000 cal BC (Schmitt et al. 2009;
Schmitt and Svedhage 2016). The land continued to rise in the succeeding millennia, though the shore-displacement curves gradually flattened out (Skar and Breivik 2018). In the Oslo Fjord area, the highest marine limit is $270 \mathrm{~m}$ above the present sea level (Holtedahl 1953), demonstrating the very strong impact of isostasy in this area.

Steep shore-displacement curves are also found in central/western and northern Norway. In parts of central/western Norway, reconstructions show a drop in relative sea level of as much as $60 \mathrm{~m}$ between 9500 and 8000 cal BC (Svendsen and Mangerud 1987). The region was, however, subjected to the Tapes transgression between c. 82004900 cal BC (9000-6000 BP, Svendsen and Mangerud 1987). Preboreal shorelines were spared in many places, but other coastal stretches were heavily eroded or covered by the rising sea (Fig. 6.3). Some parts of the ancient coast are still inundated today and can thus be compared with the situation in other parts of Europe (Bjerck 2008; Nymoen and Skar 2011a; Skar and Breivik 2018). These areas can be found at the outer coasts of southern, western and northern Norway (Fig. 6.3).

Consequently, even if land uplift is the general dominating characteristic of the Norwegian coastline, there are important areas that have been subject to a relative sea-level rise in parts of the Holocene, especially during the Tapes transgression, c. 8200-4900 cal BC (Svendsen and Mangerud 1987).

In areas where the ice cover was thin and even partially absent in the final parts of the Ice Age, parts of the Mesolithic coastline are today submerged (Fig. 6.3). These submerged coastal landscapes have received little attention in Norwegian archaeology, although the question of the effect of the Tapes transgression has gained interest through field surveys (Nummedal 1923, 1933; Bjerck 1986). It has been demonstrated that marine deposits from this transgression have covered older sites that are now preserved on dry land (Bang-Andersen 1995) due to continuous land uplift following the transgression. In other areas, movements of land and sea have cancelled each other out in such a way that Mesolithic sites are preserved at the present shoreline or in the intertidal zone (Bjerck and Olsen 1983). 


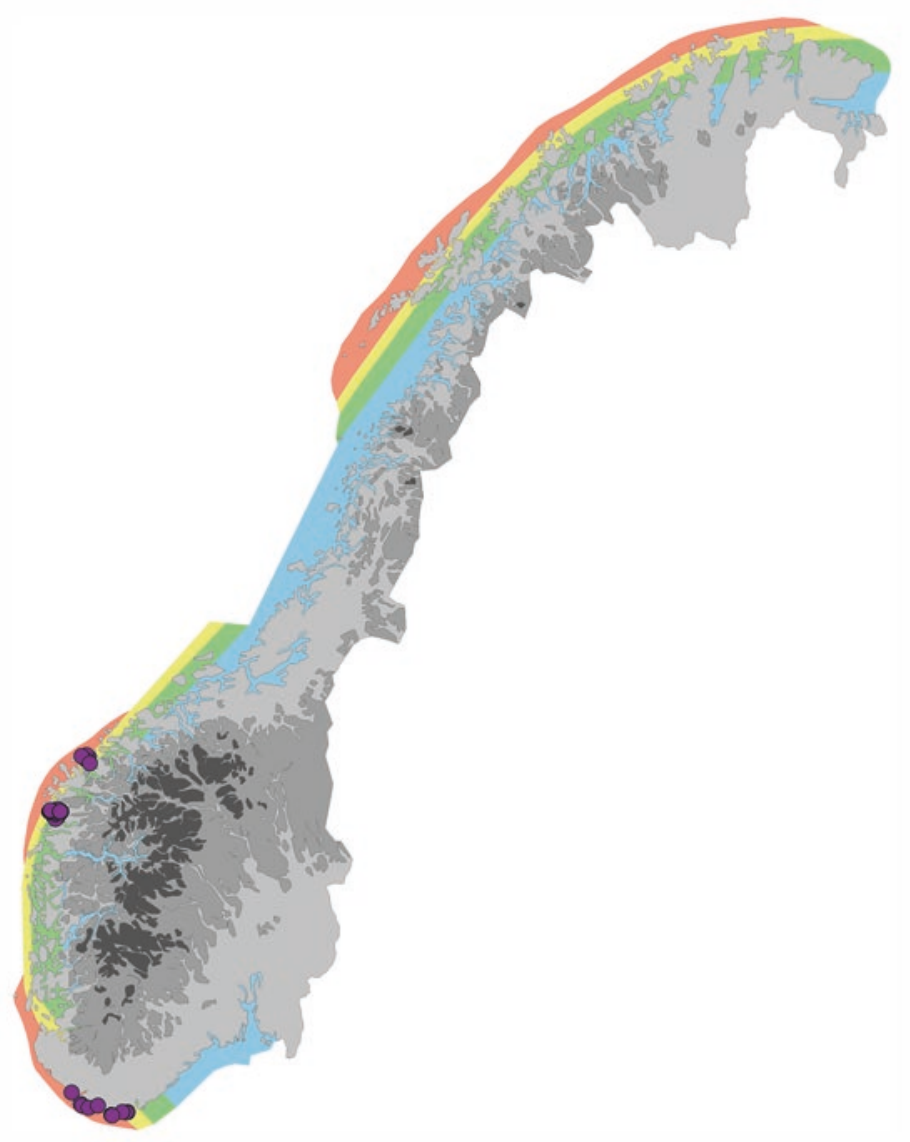

Fig. 6.3 Map showing the areas where submerged early Holocene coastlines (earlier than 9050 cal BC) are present (pink shading) and known submerged sites (purple dots). Yellow indicates areas where early Holocene shorelines lie above the current shoreline but may have been damaged by the Tapes transgression. Green indicates areas where early Holocene shorelines are above the current shoreline and the Tapes transgression level (but younger periods may have been affected by the transgression). Blue indicates areas where early Holocene sites are above the current shoreline and where there has not been a subsequent marine transgression. Further detail is shown in Fig. 6.4. Drawing by David Simpson based on information from Svendsen and Mangerud (1987), Bondevik et al. (1998), Møller and Holmeslet (1998) and Simpson (2003)

The submerged coastlines of the Early Mesolithic (c. 9300-8300 cal BC), and to some extent of the Middle Mesolithic (c. 83006300 cal BC), are situated in relatively shallow waters (less than $10 \mathrm{~m}$ depth). This can be of significance to European archaeology because coastlines of these periods elsewhere are situated in much deeper water, and consequently they are more difficult to investigate archaeologically with today's technology. Potentially, the submerged Norwegian coastlines can provide well-preserved coastal sites of the Early Mesolithic, capable of giving a unique insight into the formative processes of Mesolithic subsistence strategies, settlement patterns, population diversity and material culture during this decisive period of human history.

\subsection{The Submerged Sites}

The total number of known submerged Stone Age sites in Norway is uncertain. As long as archaeologists have been aware of the Tapes transgression, they have also been attentive to the possibility of sites below present-day sea level. However, possibly due to the thousands of sites 


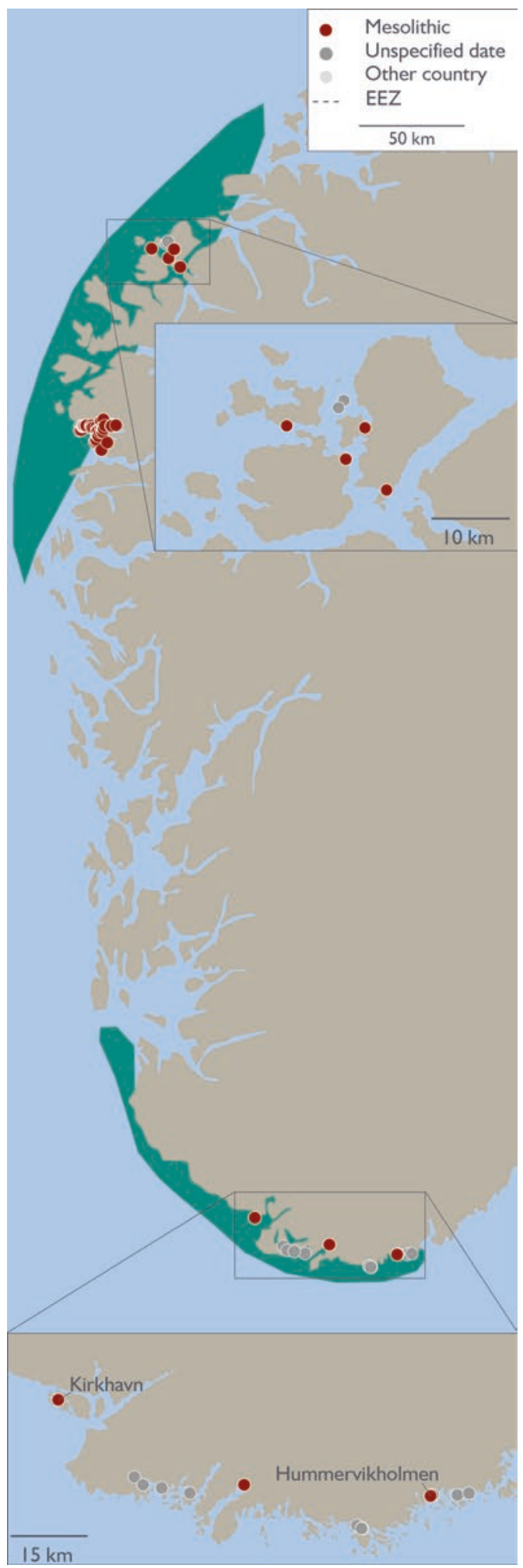

Fig. 6.4 Map of Norway showing the location of underwater Stone Age find spots currently known from the Norwegian seabed. In total, there are 86 find spots. Potential areas shaded in green are those areas of submergence where underwater sites may be expected to occur. Site information from the SPLASHCOS Viewer http://splashcos-viewer.eu. Drawing by Moritz Mennenga 

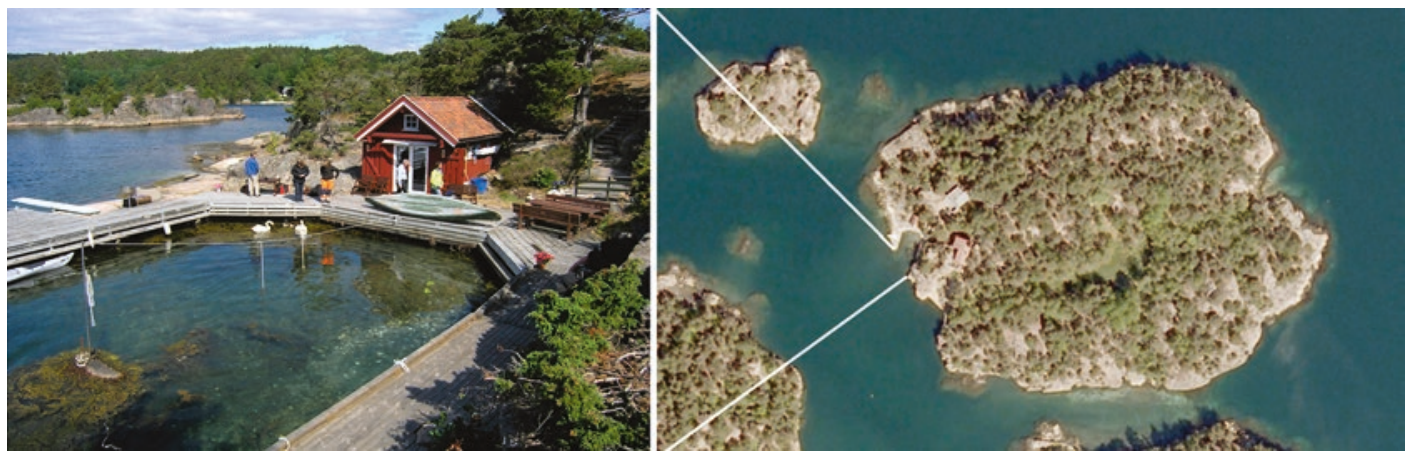

Fig. 6.5 Left: The inlet at Hummervikholmen, showing the location of Mesolithic human skeletal remains. Photo by Pål Nymoen. Copyright Norwegian Maritime Museum 2010. Right: Aerial view showing the location of the site in its wider context (http://kart.kystverket.no.)

on dry land, submerged sites have been given little attention. Hence, when more than 50 partly submerged sites were recorded in the early 1980s, the fact that they were submerged during full tide was not recorded as very significant, except as a complicating factor when recording and excavating (Olsen 1981; Bjerck and Olsen 1983).

All currently known sites from the Norwegian seafloor are situated in two of the three areas where the regression minimum was below the present sea level (Figs. 6.3 and 6.4). All sites are found in shallow waters, no deeper than $10 \mathrm{~m}$ below present average sea level. Most sites are only partly submerged, or only submerged during full tide. Since these depths are continuously exposed to wave action and tidal cycles, the sites are often substantially eroded and difficult to discover.

\subsubsection{Southern Norway}

The first reported submerged site in southern Norway was found in 1958 by a summerhouse owner who found a small collection of flint and rock-crystal artefacts while bathing on his holiday at Frivold in Mandal municipality (catalogue number C29741, Museum of Cultural History, University of Oslo). Later, several other finds were reported from the same bay (id no 29084, 48661 and 89,642 in the national registry Askeladden).

The most famous submerged Stone Age site in Norway was also found by a summer-house owner, some $15 \mathrm{~km}$ east of the 1958 site. In 1994 a cabin owner at Hummervikholmen, southernmost Norway, found human skeletal remains in his small harbour while removing sediments (Fig. 6.5). This led to the discovery of a possible ritual site from the Mesolithic, which was later excavated with interesting results (Sellevold and Skar 1999; Nymoen and Skar 2011a; Eggen et al. 2014; Nymoen 2014). Human skulls and limb bones were flushed out of the seafloor when the owner was deepening his small harbour with the aid of the water stream from the propeller of his outboard motor. The County heritage administration soon concluded that the bay revealed the oldest human skeletal remains so far found in Norway (Sellevold and Skar 1999; Nymoen and Skar 2011a). The find is comprised of the very wellpreserved bones of at least three, but perhaps as many as five, individuals (Fig. 6.6). One skull is from a female, c. 35-40 years of age at death. It is robust, with a high upper face and rather low eye sockets, resembling other Scandinavian Mesolithic female skulls (Bennike and Alexandersen 1997; Sellevold and Skar 1999). A second skull is from a man of approximately the same age (Sjöling 2014).

The Hummervikholmen individuals have been ${ }^{14} \mathrm{C}$ dated to c. $7732-7011 \mathrm{cal} \mathrm{BC} .{ }^{1}$ Chemical analyses $\left(\delta^{13} \mathrm{C}\right.$ and $\delta^{15} \mathrm{~N}$ measurements) indicate that more than $80 \%$ of the dietary protein of the individuals was derived from marine mammal resources

${ }^{1} 2 \sigma$ range ( $95.4 \%$ probability), due to the heavy marine diet an offset of 380+/-30 radiocarbon years was applied, following Mangerud et al. 2006. 


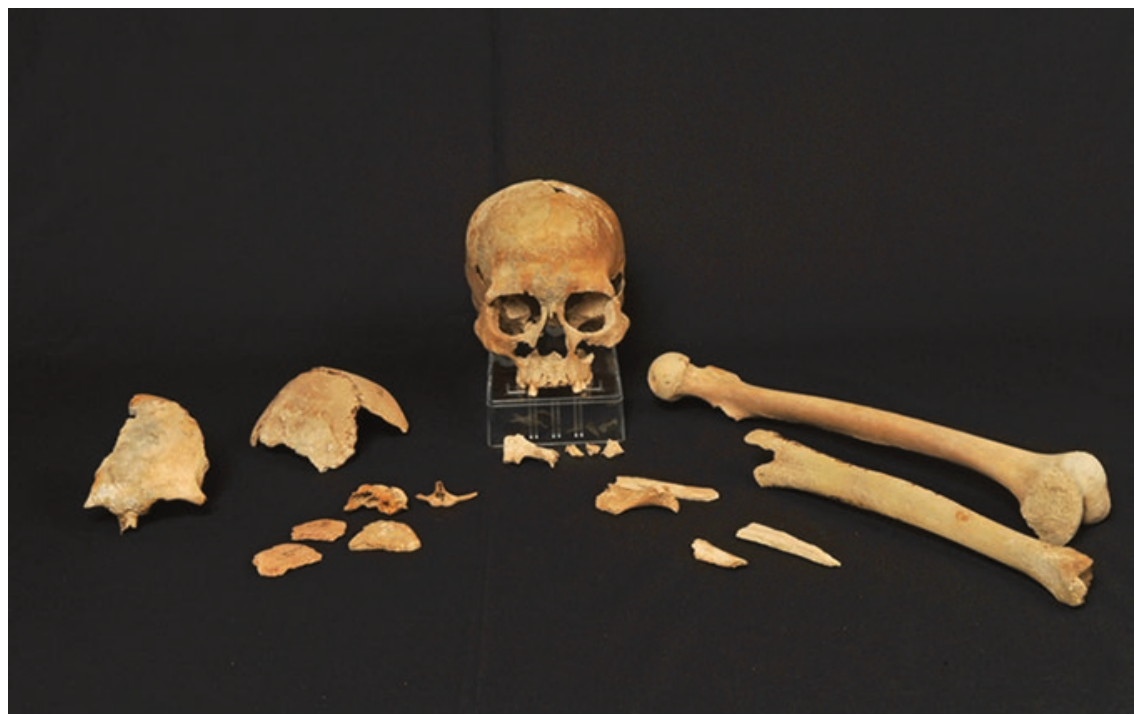

Fig. 6.6 Surviving fragments from Middle Mesolithic individuals from the seafloor of Hummervikholmen. Photo by Beate Kjørslevik. Copyright Norwegian Maritime Museum 2010

(Sellevold and Skar 1999; Skar et al. 2016). Analyses of aDNA of the female and of a male skull have confirmed a roughly 40:60\% admixture of genes derived from Western hunter gatherer versus Eastern hunter gatherer populations, thus substantiating a second Early Mesolithic migration into Norway from the East (Günther et al. 2018).

The body parts seem to have been deposited on or near the beach at a time when the sea was approximately $1.2 \mathrm{~m}$ lower than today. The site was subsequently transgressed by the rising sea (Tapes transgression) (Nymoen and Skar 2011a; Eggen et al. 2014; Nymoen 2014) and covered by an oyster bed. The human remains from Hummervikholmen may represent ritual activity, though no grave goods or other artefacts have been recorded. Surveys have not revealed any contemporaneous settlement sites on the island.

Today a dozen submerged sites are known from this southern part of the country. A few are only single finds of artefacts, without any certain context or nearby finds (Fig. 6.4) (Nymoen and Skar 2011a). Some are adjacent to sites on land and are therefore probably part of larger sites that are only partially submerged (e.g. Nymoen and Skar 2011b). Such sites can potentially be very important for research if it turns out that the submerged parts of the settlement have good conditions for preservation of organic matter. If so, the distribution of lithic artefacts can easily be studied on land, while the submerged parts can provide the kind of objects normally lost in the acid soils of the Norwegian mainland.

So far, only Middle and Late Mesolithic (c. 8300-3900 cal BC) sites are known in shallow waters, but there are good chances that even Early Mesolithic (c. 9300-8300 cal BC) sites can be recorded in deeper waters. The archipelagos of southern Norway create several sheltered zones where sediments can be deposited with little or no erosion from wind and waves. Early Holocene transgressions happened quite fast, thus Early Mesolithic sites would have been quickly sealed by sediments.

Along the coast of southern Norway where the submerged Early Mesolithic coastlines are situated, few if any Early Mesolithic settlement sites have been found on dry land. North and south of these areas, Early Mesolithic coastal sites are found in abundance (e.g. Høgestøl 1995; Reitan and Sundström 2018). Most Early Mesolithic sites are coastal sites and the presumed reason for the absence of such sites in areas with submerged coastlines could be that the sites are situated under water. The high frequency of Early Mesolithic sites on dry land gives promise of an equivalent distributional pattern along the submerged coastlines as well. 


\subsubsection{Western Norway}

Most of the known submerged Stone Age sites in Norway are found on the western coast (Figs. 6.3 and 6.4). The sea-level curves of the area (Fig. 6.2) show that the sea was as much as $10 \mathrm{~m}$ below present sea level at c. $8300 \mathrm{cal} \mathrm{BC}$, and the area probably contains thousands of sites, even if the known distribution today clusters around two separate areas. All known sites on the western coast have been found by archaeologists, but the total number is still very uncertain.

In the early 1980s archaeologist Asle Bruen Olsen was studying the use and distribution of diabase from a Mesolithic stone axe quarry close to the city of Florø on the western coast of Norway. Olsen mapped close to 100 'beach sites' containing diabase waste and artefacts from the quarry in a limited area along the outer Eikefjord (Olsen 1981). Olsen's definition of a 'beach site' was that the site was found less than 2 masl. Approximately 50 of these sites are partly or fully submerged at full tide, but Olsen's concern was not if the sites were submerged or not, and the fact that he had discovered the largest known cluster of submerged sites in Norway was given little attention.

Most of Olsen's sites are probably landing sites for offloading quarried diabase from the Stakalleneset (Stakaneset) quarry from a period when the sea level was the same or just below present. The diabase waste may therefore have been lost or discarded in shallow waters while offloading boats. The only site which has been fully excavated, however, contained more than 3600 finds of diabase, flint and quartzite, and is definitely a settlement site. The site (Askeladden id 107330) was totally submerged at full tide, and the traditional 'terrestrial' excavation could only take place during a few hours every day (Bjerck and Olsen 1983).

The quarried diabase, especially the many axe roughouts, is a distinguishing feature on all of Olsens's beach sites. This is important, because the fist-sized diabase is easily recognisable among other beach cobbles without sieving through the gravel as one has to do to find the thumb-sized pieces of worked flint or quartzite. The diabase sites are therefore highly visible compared to other kinds of Stone Age sites from the same period and thus clearly may be over- represented among the known submerged Stone Age sites in Norway.

A handful of sites without diabase were later found some $80 \mathrm{~km}$ further north along the western coast, just south of the city of Allesund. All these sites have been found by archaeologists doing environmental impact assessment studies for minor development projects. Three of the sites were found via surface collecting or test excavation at the edge of the water at full ebb (Simpson 2006; Nøttveit 2009; Sundsdal 2011), while two sites were detected by fully submerged test-pits at a depth of up to $7 \mathrm{~m}$ below present sea level.

Today's distribution of known submerged sites on the western coast, with two distinctive clusters $80 \mathrm{~km}$ apart, does not reflect the settlement pattern in the Stone Age. Rather it is the result of intensity in mapping and archaeological focus, and hundreds of more sites are most likely present in the area.

\subsubsection{Northern Norway}

The third area with a potential for traces of submerged Stone Age habitation is in the northern part of the country (Fig. 6.3). So far, no systematic investigations for submerged sites have been carried out in this huge area, even if a few areas have been subject to smaller investigations without any verified finds. In the early 1990s, diving archaeologists reported hut-like structures on a possible sunken beach ridge 4-5 $\mathrm{m}$ below present sea level at Sørøya in Finnmark. No actual artefacts were found, and later research on the relative sea-level changes in the area (Romundset et al. 2011) precludes the possibility for submerged sites at this depth. At present, no confirmed submerged sites or stray finds from Northern Norway have been reported to the national archive of archaeological finds and sites.

Parts of the Vesterålen and Lofoten archipelago in Northern Norway were ice-free during the Ice Age and tree species such as spruce and birch seem to have survived throughout the Pleistocene (Kullman 2002, 2006; Parducci et al. 2012). The reason for this is that the Gulf Stream reached the outer parts of the Lofoten-Vesterålen archipelago during the Ice Age because the continental shelf 
is quite narrow in this part of Norway (Andersen 2000, pp. 101-102). It is not unlikely that this area constituted an attractive biotope for humans in the Early Holocene, because the marine ecosystem could be supplemented by a terrestrial refuge biotope. Submarine peat, found at $2-5 \mathrm{~m}$ depth, dated to approximately $7400 \mathrm{cal} \mathrm{BC}$ is also known from Lofoten (Moe 1977; Møller 1984, p. 4; Vorren and Moe 1986). An important task for future research must therefore be to start looking for submerged sites in this area.

\subsection{Palaeoecological Evidence}

Archaeological finds of organic material are, so far, only known from two of the 86 sites from the seafloor. Both are situated in southern Norway. One of the sites is the Hummervikholmen, already described. From the island of Hidra in Vest-Agder county, a beautifully decorated pickaxe head made of bone or antler has been recovered from disturbed sediments in the Kirkhavn harbour (Fig. 6.7). The pickaxe is radiocarbondated to $7725-7535$ cal BC $(8540 \pm 75 \mathrm{BP}$, TUa 1583). Similar objects made of stone are found on dry land, dated to the same period (Glørstad 2010 and references therein). From the Ostorf cemetery in Germany similar objects made of antlers have been dated to the Middle Neolithic
(Lübke et al. 2007), indicating that such objects are among the tools used for a very long period of the Stone Age of Northern Europe.

Even though most of the submerged sites in Norway have not been subject to detailed archaeological investigations, the appearance of wellpreserved organic artefacts indicates a clear potential for finding organic remains by more systematic excavations. This stands in sharp contrast to sites on land-where mainly lithic remains are found (see also Bjerck 2008).

In the same areas where the submerged Stone Age sites are found, several spots with rich organic sediments have been detected on the seabed. Examinations of these layers indicate that some of them have been accumulated above sea level, while others have been deposited in shallow water (Nymoen and Skar 2011a). Such sites are preserved only in very sheltered waters, protected by islands and lagoons.

There are good chances that such deposits or other accumulations of organic residue on the seabed can provide crucial information about flora and fauna at the end of the Pleistocene and at the beginning of the Holocene. In Petvik, Lofoten, peat layers contain large amounts of floral remains, among them birchwood dated to $\mathrm{c}$. 7400 cal BC (Møller 1984).

Under the Middle Mesolithic deposits at Hummervikholmen, where the human remains

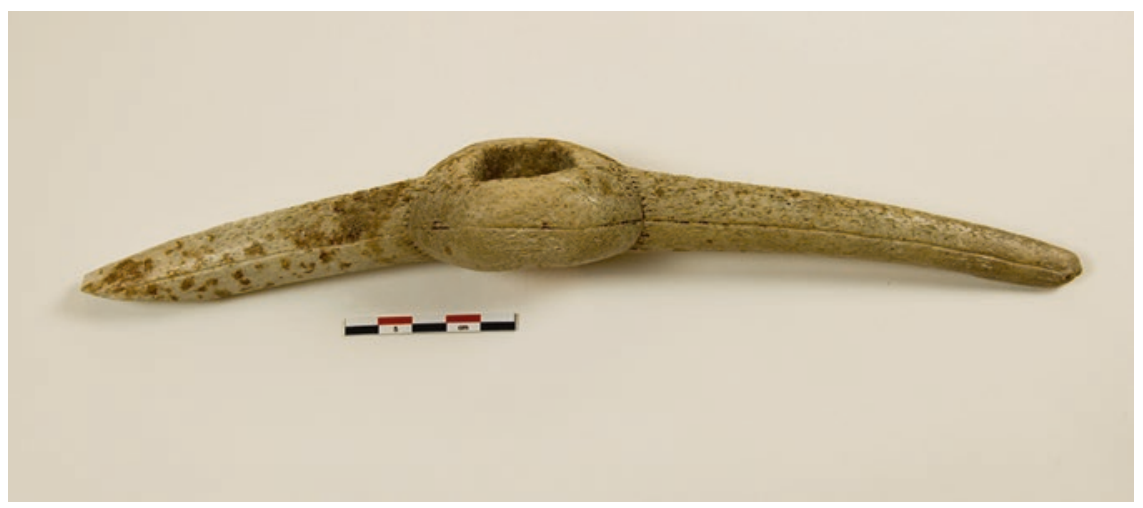

Fig. 6.7 Engraved bone pickaxe head with socket, $29 \mathrm{~cm}$ long, found during dredging in shallow water in the harbour of Kirkhavn (Scale in photo shows $1 \mathrm{~cm}$ units). Dated to $7725-7535 \mathrm{cal} \mathrm{BC}$. Isotope analysis $\left(\delta^{13} \mathrm{C}\right)$ indicates that the bone is from a marine animal (probably whale). In type and decoration, it is unique-and thus exemplifies that exploration of the submerged Stone Age landscape holds the potential to retrieve items of material culture that are not available from archaeological sites on land. Photo by Pål Nymoen. Copyright Norwegian Maritime Museum 2010 
were found, quite large pieces of pine were detected in the clay deposits. They are dated to the transitional Preboreal-Boreal period, 84517846 cal BC (Eggen et al. 2014). Gyttja dated to the Oldest Dryas is documented at even deeper levels. These kinds of deposits could therefore provide new and vital information about the earlier vegetation history of the region.

From Kaupanes, Egersund in south-western Norway, 13 antler and cranial fragments of reindeer were found in sediments in shallow water. The bones are dated to the final part of the Ice Age, 10,336-9864 cal BC $(10,255 \pm 80 \mathrm{BP}$, Bang-Andersen 2017). It is not clear how these bones ended up on the seabed. They may represent reindeer that drowned outside the continental plain and floated across the Norwegian trench to end up in south-western Norway. Even today it is not unusual that coastal currents transport carcases from Denmark to Norway (see also Jonsson 1995). A second possibility could be that the reindeer drowned on their way to pastures in Norway. The present reindeer population on Spitsbergen must have crossed large distances of sea ice, moving from island to island across Franz Josef Land to reach their present habitat (Gravlund et al. 1998; Yannic et al. 2014; Kvie et al. 2016). Similar migration patterns could have brought reindeer to Norway at the end of the Ice Age. A third possibility could be that the reindeer died on dry land and deposits of clay or silt preserved them when the sea rose. Either way, such finds are of extraordinary importance for understanding population dynamics because finds of organic remains on the bed of the North Sea from the final Pleistocene are extremely rare.

The Norwegian Cultural Heritage Act only protects sites with an established culturehistorical content. Underwater deposits of natural origin, like turf, peat or gyttja, containing vegetation or faunal material, should however also be subject to a more conscious management policy as potential heritage sites and important archives for natural history (Nymoen and Skar 2011a). The Egersund and Hummervikholmen cases prove that such sites potentially can be of great importance for the understanding of the natural and cultural history of Europe.

\subsection{Future Perspectives for Research on the Submerged Stone Age of Norway}

This brief introduction to submerged Stone Age in Norway demonstrates the important potential for developing this field of research in this part of Europe. The review also demonstrates that this subject is still at an initial stage of development. Only recently has the fact that sites are submerged along the Norwegian coast gained interest as a topic in its own right. A steadily growing level of precision concerning details in the trajectory of the local isostasy and good computer simulations of this geological process enables archaeologists to predict precisely the areas with high potential for finding submerged sites. The coastline of mainland Norway is favourably situated for discovering early Holocene sites in relatively shallow waters. Elsewhere, deep waters cover such early sites, making archaeological examination more difficult. On the southern side of the Norwegian trench there is a potential for finding sites predating the Holocene (Hammer et al. 2016). Initial investigations (Hafeez et al. 2012; Glørstad and Kvalø 2012; Glørstad et al. 2017) have, however, revealed that finding such sites involves considerable challenges.

The growing interest in submerged Stone Age in Norway and the extraordinary possibilities for studying marine occupation from the Holocene on dry land in Norway certainly define the specific knowledge potential in this heritage: The submerged sites can reveal important additional information concerning marine settlements along the Norwegian coast. Secondly, and presumably of even greater importance, the submerged Stone Age sites will likely, in favourable situations, offer excellent conditions for preservation of organic remains from human occupation, thus contributing important information on the variety and complexity of human material culture and subsistence in this part of the world. The finds from Hummervikholmen, Kirkhavn and Kaupanes clearly demonstrate the potential. 


\subsection{Submerged Sites and Cultural Heritage Management in Norway}

The Directorate for Cultural Heritage in Norway (Riksantikvaren) is responsible for the practical implementation of the Norwegian Cultural Heritage Act and the objectives laid down by the Norwegian Parliament and the Ministry of Climate and Environment. Thus, it has a general responsibility for the management of all kinds of submerged prehistoric sites.
Norway is divided into five large museum districts (Fig. 6.8). In the Troms $\varnothing$ and Trondheim districts, submerged Stone Age sites and underwater cultural heritage are managed by the University museums in the respective regions. In the Bergen, Stavanger and Oslo museum districts, this heritage is managed both by the Maritime museums and the University museums. The Maritime museums are public foundations, responsible for surveying and excavating archaeological heritage. The University museums are responsible for the finds and relevant documentation from the sites.

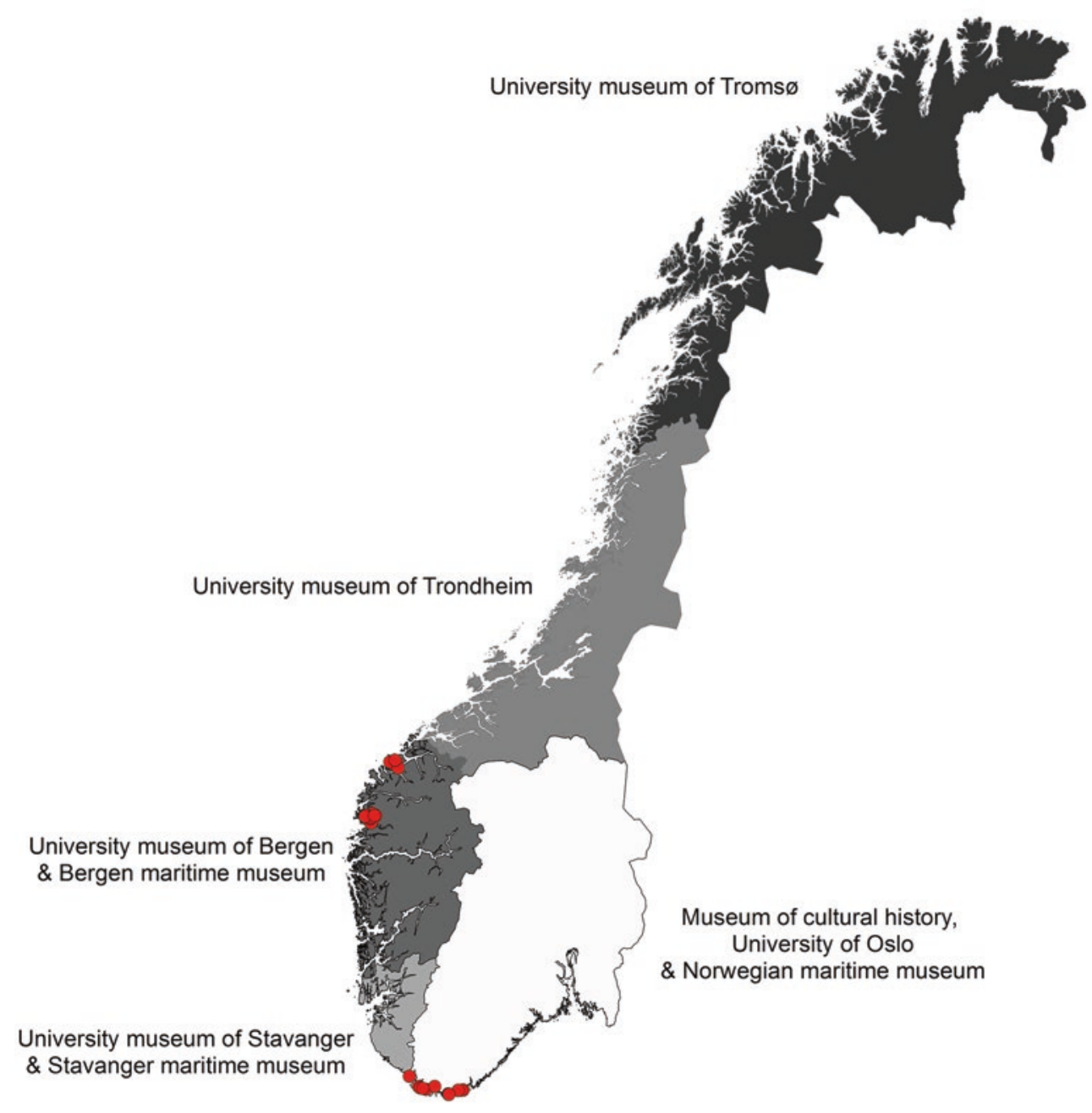

Fig. 6.8 Museum districts in Norway with institutions responsible for submerged archaeological remains. Known submerged archaeological sites are indicated by red dots 


\section{References}

Åkerlund A (1996) Human responses to shore displacement. Living by the sea in eastern middle Sweden during the Stone Age. Arkeologiska Undersøkningar Skrifter nr 16. Riksantikvarieämbetet, Stockholm

Andersen B (2000) Istider i Norge: landskap formet av istidenes breer. Universitetsforlaget, Oslo

Bagge A (1951) Fagervik. Ein Rückgrat für die Periodeneinteilung der ostschwedischen Wohnplatzund Bootaxtkulturen aus dem Mittelneolithikum. Acta Archaeol XXXII:57-118

Bang-Andersen S (1995) Mesolithic man and the rising sea spotlighted by three tapes-transgressed sites in SW Norway. In: Fischer A (ed) Man and sea in the Mesolithic. Oxbow Books, Oxford, pp 113-121

Bang-Andersen S (2017) The first one thousand yearshuman colonization and differentiated landscape use in South-Western Norway, 10,000 to 9000 BP. In: Blankholm HP (ed) The early economy and settlement in Northern Europe: pioneering, resource use, coping with change, vol 3. Equinox, Sheffield

Bennike P, Alexandersen V (1997) Danmarks Urbefolkning. Nationalmuseets Arbejdsmark, pp 143-156

Berg-Hansen IM (2017) Continuity and change in Late Glacial and Postglacial social networks; knowledge transmission and blade production methods in Ahrensburgian and Early Mesolithic North West Europe. In: Knutsson K, Knutsson H, Apel J, Glørstad $\mathrm{H}$ (eds) The Technology of Early Settlement in Northern Europe - transmission of knowledge and culture, vol 2. Equinox, Sheffield, pp 63-98

Bjerck HB (1986) The Fosna-Nøstvet problem. A consideration of archaeological units and Chronozones in the South Norwegian Mesolithic period. Nor Archaeol Rev 19(2):104-121

Bjerck HB (1994) Nordsjøfastlandet og pionerbosetningen i Norge. Viking LVII:25-58

Bjerck HB (1995) The North Sea Continent and the pioneer settlement of Norway. In: Fischer A (ed) Man and sea in the Mesolithic. Oxbow Books, Oxford, pp 131-144

Bjerck HB (2008) Norwegian mesolithic trends: a review. In: Bailey G, Spikins P (eds) Mesolithic Europe. Cambridge University Press, Singapore, pp 60-106

Bjerck HB, Olsen AB (1983) Kulturhistoriske undersøkelser på Botnaneset, Flora 1981-82. Arkeologiske rapporter 5, Historisk museum, Universitetet i Bergen

Bondevik S, Svendsen JI, Mangerud J (1998) Distinction between the Storegga tsunami and the Holocene marine transgression in coastal basin deposits of western Norway. J Quat Sci 13:529-537

Brøgger WC (1905) Strandliniens beliggenhed under stenalderen i det sydøstlige Norge. Norges geologiske undersögelser no 41. Aschehoug, Kristiania

Coles BJ (1998) Doggerland: a speculative survey. Proc Prehist Soc 64:45-81
Damlien H (2014) Eastern pioneers in westernmost territories? Current perspectives on Mesolithic huntergatherer large-scale interaction and migration within Northern Eurasia. Quat Int 419:5-16

Damlien H (2016) Between tradition and adaptation. Long-term trajectories of lithic tool-making in South Norway during the postglacial colonization and its aftermath (c. 9500-7500 cal BC). Unpublished PhD thesis, University of Stavanger, Stavanger

De Geer G (1888) Om Skandinaviens nivåforandringar under Quartorperioden. Geologiska Föreningens i Stockholm Forhandlingar, 10:366-379, 12:6-110

Eggen I, Nymoen P, Hammer $\varnothing$, Sjöling, E (2014) Excavation report and analyses from Hummervikholmen, Hallandvik, Søgne k, Vest-Agder. Museum of Cultural History, University of Oslo

Fischer A (ed) (1995) Man and sea in the Mesolithic, Oxbow Monographs 53. Oxbow, Oxford

Fredsjö Å (1953) Studier i Västsveriges äldre stenålder. Skrifter utgivna av Arkeologiska museet i Göteborg; 1. Arkeologiska Museet, Göteborg

Gaffney V, Allaby R, Bates R, Bates M, Ch'ng E, Fitch S, Garwood P, Momber G, Murgatroyd P, Pallen M, Ramsey E, Smith D, Smith O (2017) Doggerland and the lost frontiers project (2015-2020). In: Bailey G, Harff J, Sakellariou D (eds) Under the sea: archaeology and palaeolandscapes of the continental shelf. Springer, Cham, pp 305-321

Glørstad H (2010) The structure and history of the Late Mesolithic societies of the Oslo Fjord Area 6300-3800 BC. Bricoleur Press, Gothenburg

Glørstad H (2012) Where are the missing boats? The pioneer settlement of Norway as long-term history. Nor Archaeol Rev 46(1):57-80

Glørstad H (2014) Deglaciation, sea-level changes and the Holocene colonisation of Norway. In: Harff J, Bailey G, Lüth F (eds) Geology and archaeology: submerged landscapes of the continental shelf, Geological Society, vol 411. Special Publications, London, pp 9-25

Glørstad H, Kvalø F (eds) (2012) Havvind - paleogeografi og arkeologi. Kunnskapsinnhenting om bosetning i det holocene nordsjølandskapet. Arkeologisk rapport 12. Norsk Maritimt Museum, Oslo

Glørstad H, Gundersen J, Kvalø F (2017) The northern coasts of Doggerland and the colonisation of Norway at the end of the Ice Age. In: Bailey G, Harff J, Sakellariou D (eds) Under the sea: archaeology and palaeolandscapes of the continental shelf. Springer, Cham, pp 285-303

Gravlund P, Meldgaard M, Pääbo S, Arctander P (1998) Polyphyletic origin of the smallbodied, high-Arctic subspecies of tundra reindeer (Rangifer tarandus). Mol Phylogenet Evol 10:151-159

Günther T, Malmström H, Svensson EM, Omrak A, Sánchez-Quinto F, Kılınç GM, Krzewinska M, Eriksson G, Fraser M, Edlund H, Munteres AR, Coutinho A, Simões LG, Vicente M, Sjölander A, Sellevold BJ, Jørgensen R, Claes P, Shriver MD, Valdiosera C, Netea MG, Apel J, Lidén KB, Skar B, Storå J, Götherström A, Jakobsson M (2018) 
Population genomics of Mesolithic Scandinavia: investigating early postglacial migration routes and high-latitude adaptation. PLoS Biol 16(1):e2003703. https://doi.org/10.1371/journal.pbio.2003703

Hafeez A, Planke S, Hammer Ø (2012) Post-glacial paleogeography of the Southern Norwegian North Sea, Report VBPR. University of Oslo, Oslo

Hammer $\varnothing$, Planke S, Hafeez A, Hjelstuen BOB, Faleide JI, Kvalø F (2016) Agderia - a postglacial lost land in the southern Norwegian North Sea. Nor Geol Tidsskr 96(1):43-60

Høgest $\varnothing 1$ M (ed) (1995) Arkeologiske unders $\emptyset$ kelser i Rennesøy kommune, Rogaland, Sørvest-Norge. Arkeologisk Museum, Stavanger

Holtedahl O (1953) Norges geologi. Aschehoug, Oslo

Jaksland L, Persson P (eds) (2014) E18brunlanesprosjektet bind I. Forutsetninger og kulturhistorisk sammenstilling. Museum of Cultural History, University of Oslo, Oslo

Jonsson L (1995) Vertebrate fauna during the Mesolithic on the Swedish west coast. In: Fischer A (ed) Man and sea in the Mesolithic. Oxbow, Oxford, pp 147-160

Kullman L (2002) Boreal tree taxa in the central Scandes during the late-glacial: implications for late-quaternary forest history. J Biogeogr 29:1117-1124

Kullman L (2006) Late-glacial trees from Arctic coast to alpine tundra: response to Birks et al. 2005 and 2006. J Biogeogr 33:376-378

Kvie KS, Heggenes J, Anderson DG, Kholodova MV, Sipko T, Mizin I et al (2016) Colonizing the high Arctic: mitochondrial DNA reveals common origin of Eurasian archipelagic reindeer (Rangifer tarandus). PLoS One 11(11):e0165237. https://doi.org/10.1371/ journal.pone. 0165237

Lübke H, Lüth F, Terberger T (2007) Fishers or farmers? The archaeology of the Ostorf cemetery and related Neolithic finds in the light of new data. In: Larsson L, Lüth F, Terberger T (eds) Innovation and continuity non-megalithic mortuary practices in the Baltic. Verlag Phillip von Zabern, Mainz am Rhein, pp 307-338

Mangerud J, Bondevik S, Gulliksen S, Hufthammer AK, Hoisater T (2006) Marine 14C reservoir ages for 19th century whales and molluscs from the North Atlantic. Quat Sci Rev 25:3228-3245

Mikkelsen E (1975) Mesolithic in South-Eastern Norway. Nor Archaeol Rev 8(1):19-36

Moe D (1977) Nytt funn av undersjøisk torv i Norge. Naturen 1:21-23

Møller J (1984) Holocene shore displacement at Nappstraumen, Lofoten, North Norway. Norsk Geologisk Tidsskrift 64:1-5

Møller J, Holmeslet B (1998) Sealevel Change ver 3.51 (Sealev32.exe), a program for extrapolating sea level displacement curves for northern Norway, Southern Norway as well as Fennoskania and northwestern Russia. University of Troms $\varnothing$, Troms $\emptyset$

Nøttveit OM (2009) Marinarkeologiske registreringer. Reguleringsplan Varden, Ulstein. Report. Stiftelsen Bergens Sjøfartsmuseum, Bergen
Nummedal A (1923) Om flintpladsene. Nor Geol Tidsskr 7:90-141

Nummedal A (1933) Kan det finnes flintplasser på kyststrekningen mellom Kristiansand og Ålesund? Grieg, Bergen

Nymoen P (2014) Utgravningsrapport fra Hummervikholmen. Norsk Maritimt Museum, Oslo

Nymoen P, Skar B (2011a) The unappreciated cultural landscape - indications of submerged Mesolithic settlement along the Norwegian Southern Coast. In: Benjamin J, Bonsall C, Pickard C, Fischer A (eds) Submerged prehistory. Oxbow Books, Oxford, pp 38-54

Nymoen P, Skar B (2011b) Paradis - og andre indikasjoner på sub-marine lokaliteter fra mesolittisk tid langs den norske Sørlandskyst. Norsk Maritimt Museums Årbok 2011:91-115

Olsen AB (1981) Bruk av diabas i Vestnorsk steinalder. Unpublished magister thesis, University of Bergen

Olsen AB (1994) Bosetning og samfunn i Finnmarks forhistorie. Universitetsforlaget, Oslo

Parducci L, Jørgensen T, Tollefsrud MM, Elverland E, Alm T, Fontana SL, Edwards ME (2012) Glacial survival of boreal trees in northern Scandinavia. Science 335(6072):1083-1086

Reid C (1913) Submerged forests. Cambridge University Press, Cambridge

Reitan G, Sundström L (2018) Steinalderen i Aust-Agder. Arkeologiske unders $\varnothing$ kelser i forbindelse med ny E18 Tvedestrand-Arendal. Cappelen-Damm, Oslo

Romundset A, Bondevik S, Bennike O (2011) Postglacial uplift and relative sea level changes in Finnmark, Northern Norway. Quat Sci Rev 30:2398-2421

Schmitt L, Svedhage K (2016) Chronological aspects of the Hensbacka - a group of hunter- gatherers/fishers on the west coast of Sweden during the Pleistocene/ Holocene transition: an example of early coastal colonization. Danish J Archaeol 4(1):75-81

Schmitt L, Larsson S, Schrum C, Alekseeva I, Tomczak M, Svedhage K (2006) "Why they came" the colonization of the coast of western Sweden and its environmental context at the end of the last glaciation. Oxf $\mathbf{J}$ Archaeol 25(1):1-28

Schmitt L, Larsson S, Burdukiewicz J, Ziker J, Svedhage K, Zamon J, Steffen H (2009) Chronological insights, cultural change, and resource exploitation on the west coast of Sweden during the Late Palaeolithic/Early Mesolithic transition. Oxf J Archaeol 28:1-27

Sellevold BJ, Skar B (1999) The first lady of Norway. In: Gundhus G, Seip E, Ulriksen E (eds) NIKU 19941999. Kulturminneforskningens mangfold. NIKU, Oslo, pp 6-11

Simpson D (2003) SeaLevelCurvesSunm-STrond_v2.xls. Bergen Museum, University of Bergen, Bergen

Simpson D (2006) Arkeologiske undersøkelser på Eika, Sundet gnr. 71, Ulstein kommune, Møre og Romsdal. Report, Bergen Museum. University of Bergen, Bergen

Sjöling E (2014) Osteologisk analys, Obrända människoben/menneskeknokler från tidigmesolitikum, 
Humervikholmen, Søgne kommune, Vest-Agder. SAU rapport 2014:5. Museum of Cultural History, University of Oslo, Oslo

Skar B, Breivik HM (2018) Environment and adaptation of forager pioneers on Northwestern regions of Europe. In: Persson PÅ, Riede F, Skar B, Breivik HM, Johnsson L (eds) The ecology of early settlement in northern Europe. Conditions for subsistence and survival. Equinox Publishing, Sheffield, pp 1-16

Skar B, Lidén K, Eriksson G, Sellevold B (2016) A submerged Mesolithic grave site reveals remains of the first Norwegian seal hunters. In: Bjerck HB (ed) Marine ventures. Archaeological perspectives on human-sea relations. Equinox, Sheffield, pp 225-239

Sørensen M, Rankama T, Kankaanpää J, Knutsson K, Knutsson H, Melvold SA, Eriksen BV, Glørstad H (2013) The first eastern migrations of people and knowledge into Scandinavia: evidence from studies of
Mesolithic technology, 9th-8th millennium BC. Nor Archaeol Rev 46(1):19-56

Sundsdal K (2011) Rapport fra marinarkeologiske registreringer. Vannledning fra Borgarøy til Hatløy, Ulstein kommune. Stiftelsen Bergens Sjøfartsmuseum, Bergen

Svendsen JI, Mangerud J (1987) Late Weichselian and Holocene sea-level history for a cross-section of western Norway. J Quat Sci 2:113-132

Vorren KD, Moe D (1986) The early Holocene climate and sea-level changes in Lofoten and Vesterålen, North Norway. Norsk Geologisk Tidsskrift 66:135-143

Yannic G, Pellissier L, Ortego J, Lecomte N, Couturier S, Cuyler C, Dussault C, Hundertmark KJ, Irvine RJ, Kolpashikov L, Mager K, Musiani M, Parker KL, Røed KH, Sipko T, Pórisson SG, Weckworth BV, Guisan A, Bernatchez L, Côté SD (2014) Genetic diversity in caribou linked to past and future climate change. Nat Clim Chang 4(2):132-137

Open Access This chapter is licensed under the terms of the Creative Commons Attribution 4.0 International License (http://creativecommons.org/licenses/by/4.0/), which permits use, sharing, adaptation, distribution and reproduction in any medium or format, as long as you give appropriate credit to the original author(s) and the source, provide a link to the Creative Commons licence and indicate if changes were made.

The images or other third party material in this chapter are included in the chapter's Creative Commons licence, unless indicated otherwise in a credit line to the material. If material is not included in the chapter's Creative Commons licence and your intended use is not permitted by statutory regulation or exceeds the permitted use, you will need to obtain permission directly from the copyright holder. 